\title{
Ga-68 DOTATATE Positron Emission Tomography Computed Tomography Findings in Patients with Neuroendocrine Tumor Suspicion
}

\author{
Nöroendokrin Tümör Șüphesi Olan Hastalarda Ga-68 DOTATATE Pozitron Emisyon Tomografisi/Bilgisayarlı \\ Tomografi Bulguları
}

\author{
Çiğdem Soydal, Elgin Özkan, Evrim Bali, Özlem N. Küçük, Metin K. Kır
}

\begin{abstract}
Aim: We aimed to retrospectively evaluate the outcome of patients with suspected neuroendocrine tumor (NET)s who underwent Ga-68 DOTATATE Pozitrun Emission Tomography/Computed Tomography (PET/CT) imaging and to describe the value of Ga-68 DOTATATE PET/CT in the detection of NETs.

Material and Method: Ga-68 DOTATATE PET/CT images of 35 patients (26M; 9F, mean age; $45.2 \pm 5.4$ years) with suspected NET were analyzed retrospectively. Suspicion of NET was due to clinical symptoms (n:12), elevated biochemical markers (n:19) and/or radiological findings (n:13). Clinical/imaging follow-up and/or histopathological confirmation was used as reference standard.

Results: Based on the reference standard 13 of 35 patients had NET. Ga-68 DOTATATE PET/CT was positive in 12 out of 13 patients and it was false negative in 1 patient. Pancreas was the commonest site of the primary tumor. Ga-68 DOTATATE was TP(true pozitive), FP (False Positive), TN (True Negative) and FN (False Negative) in, 12, 2, 20 and 1, patients respectively. Sensitivity, specificity, Pozitive Pedictive Value (PPV), Negative Pedictive Value (NPV), and accuracy of Ga-68 DOTATATE PET/CT was calculated as $85 \%, 95 \%, 92 \%, 90 \%$ and $91 \%$, respectively.

Conclusion: Ga-68 DOTATATE PET/CT has a high accuracy in the detection of suspected NET. It can be used for searching possible NET in patients with suspicion.

Key Words: Neuroendocrine Tumor, Ga-68 DOTATATE, PET/CT

Amaç: Nöroendokrin Tümör (NET) șüphesi ile Ga-68 DOTATATE Pozitron Emisyon Tomografisi/Bilgisayarlı Tomografi (PET/BT) görüntüleme yapılan hastaların sonuçlarını retrospektif olarak değerlendirmeyi ve NET saptanmasında Ga68 DOTATATE PET/BT'nin yerini tanımlamayı amaçladık.

Gereç ve Yöntem: Nöroendokrin tumor șüphesi ile Ga-68 DOTATATE PET/BT yapılan 35 hastanın (26E; 9K, ort. yaș: $45.2 \pm 5.4$ ) sonuçları retrospektif olarak analiz edildi. Nöroendokrin tumor süphesi klinik bulgular (n:12), biyokimyasal parametrelerde yükselme $(n: 19)$ ve radyolojik bulgular $(n: 13)$ idi. Klinik/radyolojik takip ve/veya histopatolojik inceleme referans standart olarak kullanıldı.

Bulgular: Referans standart temel alınarak 35 hastanın 13'ü NET olarak kabul edildi. Ga-68 DOTATATE PET/BT 13 hastanın 12 'sinde pozitif ve 1 'inde yalancı negative idi. En sık primer tümör lokalizayonu pankreas idi. Ga-68 DOTATATE PET/BT 12, 2, 20 and 1 hastada sırası ile Gerçek Pozitif (GP), Yalancı Pozitif (YP), Gerçek Negatif (GN) ve Yalancı Negatif (YN) idi. Ga-68 DOTATATE PET/BT için duyarlıık, özgüllük, pozitif pediatrig değer, negatif pediatrik değer ve doğruluk sırası ile $\% 85, \% 95, \% 92, \% 90$ ve $\% 91 \%$ olarak hesaplandı.

Sonuç: Ga-68 DOTATATE PET/BT NET șüphesinde tümör odağının saptanmasında yüksek doğruluğa sahiptir ve bu amaçla kullanılabilir.

Anahtar Sözcükler: Nöroendokrin Tümör, Ga-68 DOTATATE, PET/BT
\end{abstract}

Neuroendocrine tumors (NETs) are a heterogeneous group of neoplasm arising form neuroendocrine cells (1). Although most of the NETs originates from gastroenteropancreatic tract, endocrine glands such as thyroid, pituitary and adrenal, respiratory tract and skin could be the primary location of NETs. In addition to their variable biological behavior, small size and diverse locations of most NETs make the diagnosis difficult. Typical symptoms are called as carcinoid syndrome, however they are not specific for NETs diagnosis. Moreover, carcinoid syndrome is not seen in most cases and clinical symptoms are usually nonspecific in these cases. Fifty- $70 \%$ of NETs do not produce any specific biochemical markers (2). Chromogranin A (CrA) is nonspecific marker and has limited sensitivity and specificity (3). Conventional imaging tools and endoscopic techniques might be nondiagnostic or negative for diagnosis of NETs (4). 
Radiolabeled (with Tc-99m, In-111 or Ga68) somatostatin analogs have been used for imaging of NETs. Especially, positron emission tomography (PET)/computed tomography (CT) with Ga-68 labeled DOTA-peptides have been shown superior to conventional methods as well as In111 octreotid scintigraphy (5-6). According to these encouraging results, PET/CT with Ga-68 labeled DOTA-peptides has been performed to search possible NET in patients with clinical, biochemical or radiological suspicion of NET. In this study, we aimed to evaluate retrospectively the outcome of patients with suspected NETs who underwent Ga-68 DOTATATE $\mathrm{PET} / \mathrm{CT}$ imaging and to describe the value of Ga-68 DOTATATE $\mathrm{PET} / \mathrm{CT}$ in the detection of NETs.

\section{Material and Methods}

\subsection{Patients}

Thirty-five (26M; 9F, mean age; 45.2 \pm 5.4 years) patients who underwent Ga-68 DOTATATE PET/CT for clinical/ biochemical or radiological suspicion of NET were included in the study. Twelve patients had symptoms that could be related to NET, 19 patients had elevated biochemical markers such as $\mathrm{CrA}$ or gastrin and 13 patients had radiological findings. Some of patients presented with more than one of the findings. Histopathological confirmation (2 FNAB of pancreas, 1 pancreatectomy, 1 transbronchial lung biopsy, 1 endoscopic stomach and 1 duodenum biopsy) was used for every patient who was ethically and technically suitable. A combination of clinical, biochemical and imaging follow-up at least 6 (mean: 24.6 \pm 12.4 months) months has been preferred as reference standard at the rest of the patients $(n=29)$.

\subsection{Ga-68 DOTATATE PET/CT imaging}

PET/CT images were acquired with Discovery ST PET/CT scanner (General Electric, Milwaukee, Wisconsin, USA). Synthesis of Ga-68 DOTATATE was performed by automated synthesis unit (Scintomics
GmbH, Fürstenfeldbruck, Germany). Images were obtained approximately 1 hour after an intravenous injection of approximately $100 \mathrm{MBq}$ of Ga-68 DOTATATE. An oral contrast agent was given to patients with abdominal lesions in conventional imaging methods. Whole body PET/CT imaging was performed while patients were in supine position from the vertex to the mid thighs. Computed Tomography (CT) image was obtained from the integrated Pozitrun Emission Tomography/ Computed Tomography PET/CT scanner with the use of a standardized protocol involving 140 $\mathrm{kV}, 70 \mathrm{~mA}$, a tube rotation time of $0.5 \mathrm{~s}$ per rotation, a pitch of 6 and a section thickness of $5 \mathrm{~mm}$. Immediately after the CT part, Positron emmission tomography images were acquired for 5 minutes per bed position. PET images were reconstructed using non-contrast CT data for attenuation correction. PET/CT images were evaluated by visually for regions of pathologically increased tracer uptake that could not be accepted as normal physiologic activity.

\subsection{Statistical Analysis}

Data were summarized as mean \pm standard deviation. Sensitivity, specificity, PPV, NPV and accuracy

of Ga-68 DOTATATE PET/CT were calculated. All statistical analyses were performed using SPSS computer statistical software (version 16.0; SPSS, Chicago, Illinois).

\section{Results}

The most common clinical symptom was diarrhea with 6 patients $(17 \%)$. Eight $(22 \%)$ patients had elevated CrA and $4(11 \%)$ patients Gastrin levels. Radiological suspicion of NET was due to pancreatic masses in pancreas Magnetic resonance imaging $(n=13)$. In our study the most common indication of Ga-68 DOTATATE $\mathrm{PET} / \mathrm{CT}$ is elevated blood biochemical marker levels. PET/CT was TN in 8 and FP in 1 out of 13 patients. Details of patient characteristics were demonstrated in Table 1.

Ga-68 DOTATATE was normal in 21 patients. Based on the reference standard Ga-68 DOTATATE $\mathrm{PET} / \mathrm{CT}$ was $\mathrm{FN}$ in one patient who was diagnosed as VIPoma with typical clinical presentation, detection of millimetric pancreatic lesion in the follow-up MRI and relief of symptoms with long acting somatostatin analog treatment. Details of FN and FP findings were demonstrated in Table 2. Based on

Table 1: Details of patient characteristics

\begin{tabular}{lrc}
\hline Characteristics & n (\%) \\
\hline Gender & Female & $9(25)$ \\
& Male & $26(75)$ \\
Reason of Suspicion & & \\
Clinical symptoms & & $12(34)$ \\
& Diarrhea & $6(17)$ \\
& Hypoglycemia & $3(9)$ \\
Biochemical markers & Other & $3(9)$ \\
& & $19(54)$ \\
& CrA & $8(20)$ \\
& Gastrin & $4(10)$ \\
Radiological Findings & Neuron specific enolase & $4(10)$ \\
\hline
\end{tabular}

Table 2: Details of False Positive and False Negative Findings

\begin{tabular}{|c|c|c|c|c|c|}
\hline $\begin{array}{c}\text { Patient } \\
\text { No }\end{array}$ & Age & Gender & Indicationfor Ga-68 DOTATATE PET/CT & Gold standart & Ga-68 DOTATATE PET/CT \\
\hline 1 & 57 & $\mathrm{M}$ & 18 mm suspected mass in pancreatic tail & Ectopicspleen & FP \\
2 & 36 & $\mathrm{~F}$ & Elevated CrA levels and chronic diarrea & VIPoma & FN \\
3 & 46 & $\mathrm{~F}$ & Elevated CrA levels & Duedonitis & FP \\
\hline
\end{tabular}


the reference standard 13 of 35 patients had neuroendocrine tumor. Ga-68 DOTATATE PET/CT was positive in 12 of 13 patients and it was false negative in 1 patient. Pancreas was the commonest site of primary tumor ( $\mathrm{n}=7$, Figure 1$)$ ), the second site was the small bowel (n=6). Ga-68 DOTATATE PET/CT was TP in 6 out of 7 patients with pancreatic mass. Additionally it was detected peripancreatic lymph node metastases in 1 patient. Ga-68 DOTATATE PET/CT was FP in 2 patients and histopathological examinations have resulted as ectopic spleen tissue (Figure 2) in pancreas and duedonitis in these patients. Sensitivity, specificity, PPV, NPV and accuracy of Ga-68 DOTATATE PET/CT were calculated as $85 \%$, $95 \%, \quad 92 \%, \quad 90 \%$ and $91 \%$, respectively.

\section{Discussion}

Today PET/CT with Ga-68 DOTApeptides has been used for evaluation of NET patients (7-9). High accuracy

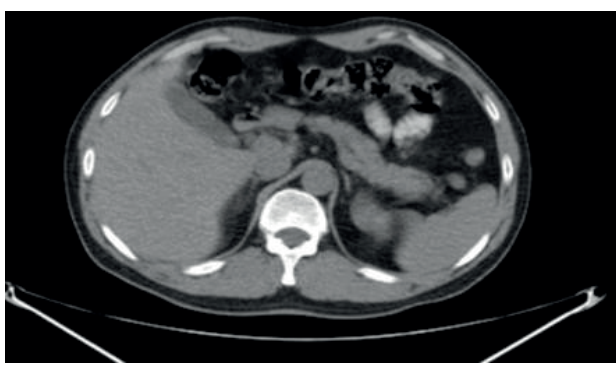

of Ga-68 DOTA-peptide PET/CT in the detection of NET lesions has been reported in different studies (7-11). Presence of increased uptake areas other than physiological uptake sites demonstrates the lesions overexpressing Somatostatin Receptor (SSTR). Although exclusion of inflammatory causes of increased uptake is done, final diagnosis of NET should be confirmed by pathological examination. Despite of its widely availability, relatively non-invasive nature and advantages of whole body screening, routine usage of Ga-68 DOTA-peptide PET/CT in the suspicion of NET has not widely been accepted.

This study has been established to evaluate the outcome of patients with suspected NETs who underwent Ga-68 DOTATATE PET/CT imaging. In our study the most common indication of Ga-68 DOTATATE PET/CT is elevated blood biochemical marker levels. PET/CT was TN in 8 and FP in 1 out of 13 patients. These results support the data about low sensitivity

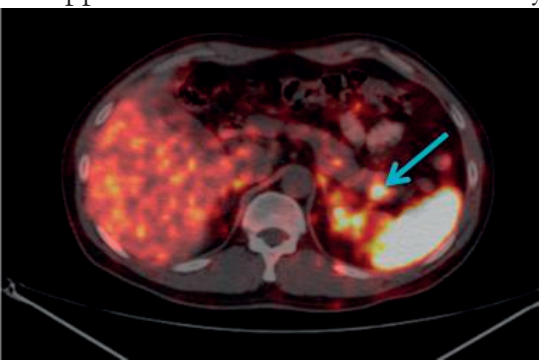

Figure 1: Transaxial CT and Fused PET/CT images of 63 years old male patient who underwent Ga-68 DOTATATE PET/CT for $17 \mathrm{~mm}$ pancreatic tail mass and elevated $\mathrm{CrA}$
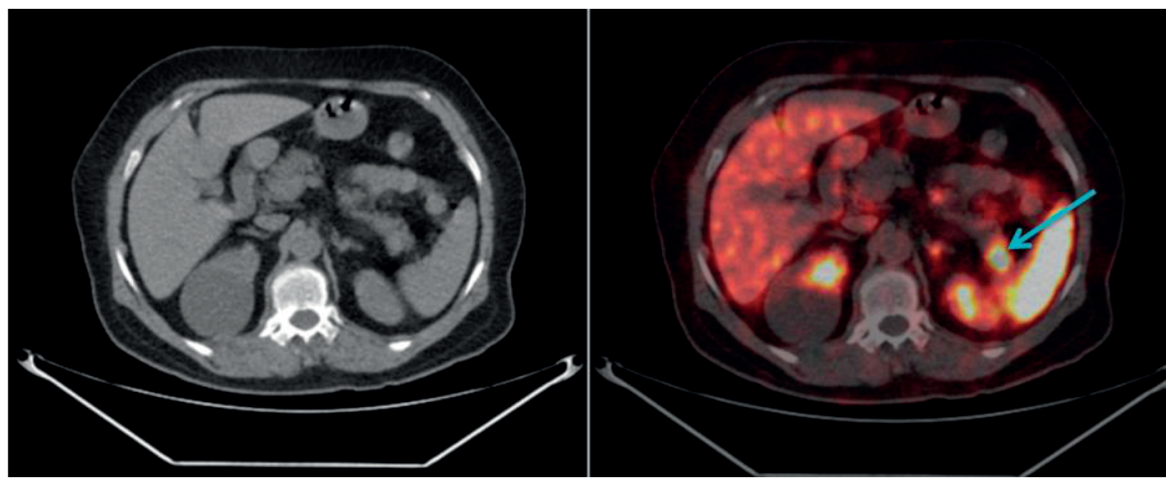

Figure 2: Transaxial CT and Fused PET/CT images 58 years old male patient who underwent Ga-68 DOTATATE PET/CT for $18 \mathrm{~mm}$ pancreatic tail mass. Ga-68 DOTATATE uptake was seen in pancreatic mass (arrow). Distal pancreatectomy was performed following PET/CT and ectopic spleen tissue was reported in pathological examination. of $\mathrm{Cr}-\mathrm{A}$ in the diagnosis of NET (12). Elevated Cr-A levels can be detected in several malignant and benign conditions such as cardiovascular, gastrointestinal, pulmonary, rheumatologic and endocrine disorders (13-16). Additionally a group of medications mostly commonly proton pump inhibitors may affect serum $\mathrm{Cr}$ A levels (17). In 3 patients those have accompanying radiological findings PET/CT was True Positive (TP). For these reasons Ga-68 DOTATATE PET/CT seems to be more helpful in patients with both elevated biochemical markers and radiological findings.

Ga-68 DOTATATE PET/CT was FP and $\mathrm{FN}$ in 2 and 1 patient, respectively. Histopathological examinations have resulted as ectopic spleen tissue in pancreas and duedonitis in FP patients. Ectopic spleen tissue in pancreas is not uncommon condition and it can mimic pancreatic NET (17, 18). Presence of ectopic pancreatic tissue should be considered in suspected patients and Tc-99m Colloid scintigraphy may help to differential diagnosis (18). Another common false positive Ga-68 DOTA-peptide uptake cause is inflammatory changes (19). Endoscopic confirmation in patients who are suitable or repeat of imaging after anti-inflammatory/ antibiotics therapy can eliminate FP uptake. Detection rate of VIPoma with Ga-68 DOTA-peptide PET/CT has been reported high (20). Contrarily in our series we had only one patient with VIPoma and Ga-68 DOTATATE PET/CT was FN in that patient. In our patient, possible explanation for this FN finding could be spatial resolution limitation of PET due to millimetric dimension of pancreatic lesion.

Major limitations of present study are the small number of patient population and retrospective design. However recent literature has a few studies on the role of Ga-68 DOTA-peptide $\mathrm{PET} / \mathrm{CT}$ in the management of patients with neuroendocrine tumor suspicion. For this reason we thought results of this series could be worth to share. 


\section{Conclusion}

Ga-68 DOTATATE PET/CT has a high accuracy in the detection of suspected neuroendocrine tumor.

\section{REFERENCES}

1. Kaltsas GA, Besser GM, Grossman AB. The diagnosis and medical management of advanced neuroendocrine tumors. Endocr Rev. 2004;25:458-511.

2. Oberg K, Akerström G, Rindi G, Jelic S; ESMO Guidelines Working Group. Neuroendocrinegastroenteropancreatictu mours: ESMO Clinical Practice Guidelines for diagnosis, treatment and follow-up.Ann Oncol. 2010 May;21Suppl 5: 223-7/227.

3. Modlin IM, Gustafsson BI, Moss SF, et al. Chromogranin A--biological function and clinical utility in neuro endocrine tumor disease.Ann SurgOncol. 2010;17:2427-2443.

4. Alexandraki KI, Kaltsas G. Gastroenteropancreatic neuroendocrine tumors: new insights in the diagnosis and therapy.Endocrine. 2012;41:40-52.

5. Naswa N, Sharma P, Kumar A, et al. Gallium-68-DOTA-NOC PET/CT of patients with gastroenteropancreatic neuroendocrine tumors: a prospective single-center study.AJR Am J Roentgenol. 2011;197:1221-1228.

6. Kowalski J, Henze M, Schuhmacher J, et al. Evaluation of positron emission tomography imaging using [68Ga]DOTA-D Phe(1)-Tyr(3)-Octreotide in comparison to [111In]-DTPAOC SPECT. First results in patients with neuroendocrine tumors.Mol Imaging Biol. 2003;5:42-48.
Although FP and FN findings are rare, inflammatory processes and milimetric tumors should be considered. In selected patients, Ga68 DOTATATE PET/CT could be used to search possible neuroendocrine tumor focus and it is more successful in patients with elevated tumor marker and radiological findings.
7. Gabriel M, Decristoforo C, Kendler D, et al. 68Ga-DOTA-Tyr3-octreotide PET in neuroendocrine tumors: comparison with somatostatin receptor scintigraphy and CT.J Nucl Med. 2007;48:508-518.

8. Adams S, Baum R, Rink T, et al. Limited value of fluorine-18 fluorodeoxyglucose positron emission tomography for the imaging of neuroendocrine tumours.Eur J Nucl Med. 1998;25:79-83

9. Ambrosini V, Campana D, Bodei L, et al. 68Ga-DOTANOC PET/CT clinical impact in patients with neuroendocrine tumors.J Nucl Med. 2010;51:669-673

10. Buchmann I, Henze M, Engelbrecht S, et al. Comparison of 68Ga-DOTATOC PET and 111In-DTPAOC (Octreoscan) SPECT in patients with neuroendocrine tumours.Eur J Nucl Med Mol Imaging. 2007;34:1617-1626.

11. Haug AR1, Cindea-Drimus R, Auernhammer CJ, et al. The role of ${ }^{68} \mathrm{Ga}$-DOTATATE PET/CT in suspected neuroendocrine tumors.J Nucl Med. 2012;53:1686-1692.

12. Modlin IM, Gustafsson BI, Moss SF, et al. Chromogranin A--biological function and clinical utility in neuro endocrine tumor disease. Ann Surg Oncol. 2010;17:2427-2443.

13. Spadaro A, Ajello A, Morace C, et al. Serum chromogranin-A in hepatocellular carcinoma: diagnostic utility and limits. World J Gastroenterol. 2005;11:19871990.
14. Malaguarnera M, Cristaldi E, Cammalleri L, et al. Elevated chromogranin A ( $\mathrm{CrA})$ serum levels in the patients with advanced pancreatic cancer. Arch Gerontol Geriatr. 2009;48:213-217.

15. Sciola V, Massironi S, Conte D, et al. Plasma chromogranin a in patients with inflammatory bowel disease. Inflamm Bowel Dis. 2009;15:867-871.

16. Larsen AI, Helle KB, Christensen M, et al. Effect of exercise training on chromogranin A and relationship to $\mathrm{N}$ ANP and inflammatory cytokines in patients with chronic heart failure.Int J Cardiol. 2008;127:117-120.

17. Zhu HX, Lou WH, Kuang T'T, Wang DS.Post-splenectomy intrapancreatic accessory spleen mimicking endocrine tumor of the pancreas. Int J Surg Case Rep. 2014 15;5:1151-1153

18. Collarino A1, Del Ciello A, Perotti G, Rufini V.Intrapancreatic Accessory Spleen Detected by 68Ga DOTANOC $\mathrm{PET} / \mathrm{CT}$ and $99 \mathrm{~m}$ Tc-Colloid SPECT/CT Scintigraphy. Clin Nucl Med. 2014 Sep 30.

19. Kumar V, Boddeti DK.(68)Garadiopharmaceuticals for PET imaging of infection and inflammation. Recent Results Cancer Res. 2013;194:189-219.

20. Virgolini I1, Traub-Weidinger $T$, Decristoforo C. Nuclear medicine in the detection and management of pancreatic islet-cell tumours. Best Pract Res Clin Endocrinol Metab. 2005;19:213-227. 